\title{
LONG-TERM STABILITY OF AN ANTERIOR OPEN-BITE MALOCCLUSION TREATED IN THE MIXED DENTITION: A CASE REPORT
}

\author{
ESTABILIDADE A LONGO PRAZO DO TRATAMENTO DA MORDIDA ABERTA ANTERIOR \\ NA DENTADURA MISTA: RELATO DE CASO CLÍNICO
}

\begin{abstract}
Márcio Rodrigues de ALMEIDA ${ }^{1}$, Renato Rodrigues de ALMEIDA ${ }^{3}$, Ana Claúdia de Castro Ferreira CONTI', Ricardo de Lima NAVARRO ${ }^{1,2}$, Giovani de Oliveira CORREA ${ }^{4}$, Cristiane Aparecida de OLIVEIRA ${ }^{5}$, Paula Vanessa Pedron OLTRAMARI ${ }^{1}$
\end{abstract}

1- DDS, MSc, PhD, Assistant Professor of Orthodontics of UNINGÁ Dental School, Maringá-PR.

2- DDS, MSc, PhD, Assistant Professor of Oral and Maxillofacial Surgery of UNINGÁ Dental School, Maringá-PR.

3- DDS, MSc, PhD, Coordinate Professor of especialization program in Orthodontics of UNINGÁ Dental School, Maringá-PR - Advanced Unit in Bauru, CORA.

4- DDS, MSc, PhD,Assistant Professor of Dental Materials of UNINGÁ Dental School, Maringá-PR.

5- DDS, MSc, PhD,Assistant Professor of Pedodhontics of UNINGÁ Dental School, Maringá-PR.

Corresponding address: Márcio Rodrigues de Almeida - Rua Manoel Pereira Rolla, 18-09. - Phone/Fax: (14) 3226-1411

Jd. Planalto, CEP 17012-190, Bauru-SP - e-mail: marcioralmeida@uol.com.br

Received: November 13, 2006 - Modification: November 30, 2006 - Accepted: December 14, 2006

\begin{abstract}
A

clinical case with anterior open-bite, treated in the mixed dentition, is presented. This approach demonstrates one of the possible approaches of treatment, which is capable of interfering with growth and redirecting its vectors. Orthodontic and orthopedic methods were used, consisting of slow maxillary expansion, through a fixed palatal crib soldered in a bi-helix appliance, and high-pull traction on the mandible for 16 hours a day. After eight years of follow-up, stable outcomes were accomplished. These results may be explained by the fact that treatments were performed at the appropriate period of development, thus establishing perioral muscular equilibrium, matching the final period of facial growth. The combination of orthodontic and orthopedic treatments was necessary to prevent the need of further orthognathic surgery treatment.

Uniterms:: Open-bite; Malocclusion; Tongue habits; Orthodontics, preventive
\end{abstract}

\begin{abstract}
RESUMO
A

presentou-se um relato de caso clínico de mordida aberta anterior, tratada em dentadura mista, demonstrando uma das possíveis formas de tratamento, capaz de interferir no crescimento e redirecionar seus vetores. Os protocolos ortodônticos e ortopédicos utilizados foram a expansão lenta da maxila, utilizando grade palatina soldada a um expansor bihélice, com tração alta na mandíbula, num período diário de 16 horas. Oito anos de estabilidade foram alcançados, explicados pelo fato de o tratamento ter sido conduzido no momento oportuno do desenvolvimento, o que estabeleceu equilíbrio entre os músculos peribucais, em conjunto com o período final do crescimento. A combinação do tratamento ortodôntico e ortopédico foi necessária para se evitar a necessidade de tratamento cirúrgico.

Unitermos: Mordida aberta; Hábitos de língua; Ortodontia preventiva.
\end{abstract}




\section{INTRODUCTION}

The anterior open-bite can be defined as the presence of negative overbite between the incisal edges of the maxillary and mandibular teeth, with the posterior teeth in occlusion ${ }^{1-}$ ${ }^{4}$. Generally, an anterior open-bite is a kind of malocclusion that causes esthetic problems, impairs mastication and articulation, thus creating unfavorable conditions for a child's emotional development ${ }^{5}$.

In the mixed dentition, the prevalence of open-bite can reach $17 \%{ }^{6}$, caused by factors such as the partial eruption of the incisors, abnormal size of lymphoid tissue provoking alterations in the tongue's posture, persistence of infantile swallow, and the occurrence of oral habits ${ }^{7}$.

According to many authors, the incidence decreases with age ${ }^{6,8,9}$, stabilizing around $2 \%$ in Caucasian and $16 \%$ in black African-American teenagers ${ }^{10}$. This decrease accounts for normal occlusal development, neural maturation of the child favoring the cessation of oral habits, the decrease in size of adenoids, and the establishment of normal adult swallow ${ }^{2,11}$.

In the etiology of the anterior open-bite there are factors related to oral habits, abnormal size or function of the tongue, oral breathing, vertical growth pattern (predisposing to openbite), and congenital or acquired diseases ${ }^{11}$. Among the most frequent habits are finger-sucking, pacifiers, altered labial postures and tongue habits ${ }^{2}$. Vertical malocclusions result from the interaction of several etiologic factors, with genetic and/or environmental origin. The prognosis may be good to poor according to the severity and associated etiology. Swallowing with tongue thrusting is frequently observed in children up to ten years old with or without open-bite. This frequency is reduced after this age, reaching $2.7 \%$ in the adolescence $^{12}$. Other aspects that may break the oral balance, as adenoid hypertrophy, increased tonsils, allergy, excess of nasal cartilage, septal deviation, and chronic coryza, may lead to mouth breathing and anterior tongue positioning during swallowing, thereby affecting the position of incisors, both inducing buccal movement and limitating their correct eruption ${ }^{13}$.

There are three types of open-bite malocclusion in the mixed dentition period(1): dentoalveolar, skeletal and a combined open-bite. Most skeletal open-bites are probably at least partially attributable to abnormal perioral muscle function ${ }^{14}$. In skeletal open-bite there are craniofacial dysplasias, characterized by a counter-clockwise rotation of the palatal process, associated with a longer anterior face height, large gonial angle, short ramus, and maxillary and mandibular dentoalveolar hyperplasia ${ }^{1,2,11,15}$.

Many authors emphasize that the skeletal open-bite should be treated early in the mixed dentition ${ }^{3,4,16}$, since besides interfering with facial growth, the early treatment improves facial appearance and the child's self-esteem, reducing the possibility of relapse and thereby increasing the stability ${ }^{17}$. Taking this into account, the long-term stability of anterior open-bite patients aged nearly 12 years old treated with fixed appliances and without extractions was studied $^{18}$. The authors concluded that $61.9 \%$ of the patients presented stable occlusion. In another study, Lopez-Gavito, et al. ${ }^{10}$, in 1985, longitudinally followed 41 patients treated with fixed appliances and headgear for 10 years post-retention, and observed $35 \%$ of relapse of approximately $3 \mathrm{~mm}$ or more. English ${ }^{16}$, in 2002, stated that, if no treatment is performed, maintenance of the malocclusion in patients with vertical growth pattern with anterior openbite may result in further need of surgical treatment.

The treatment of the open-bite in the late mixed dentition, with a severe tongue thrust or posture problem, may be unsuccessful, and depends on the severity of the malocclusion and the possibility of dentoalveolar compensation $^{7,19}$. In addition, a long retention phase is necessary before abnormal perioral muscle function can be reduced.

The objective of this work was to document a clinical case of anterior open-bite presented in the mixed dentition, successfully treated by orthodontic and orthopedic methods, emphasizing the importance of early treatment as a means of preventing the need for orthognathic surgery.

\section{CASE REPORT}

A female patient, 5 years and 2 months old, with an excessive vertical growth, presenting an anterior open-bite with contact only in the molar region attended our clinic (Figures 1 and 2). This malocclusion was classified as dentoskeletal, initially related to a thumb-sucking resulting in secondary tongue thrust. The patient was healthy, and had no obstruction of the nasopharyngeal airway. The patient presented a vertical growth pattern of the face, as can be seen in Table 1.

The treatment proposed was a fixed palatal crib soldered on the bihelix appliance (Figure 3), and high pull traction on the mandible for 16 hours a day, applying $500 \mathrm{~g}$ of force, during the entire treatment, in an attempt to rotate the mandible counter-clockwise with an intrusive force in the posterior region. Following this 3-year process, the patient was allowed a period of rest and observation (Figure 4). Right after she was subjected to full fixed appliance, with edgewise mechanotherapy, over a 9 month period.

At the end of the treatment, it could be noticed, by the clinical characteristics (Figures 5 and 6) and also by the cephalometric measures (Table 1), that the initial proposal was successful. The anterior open-bite was corrected, followed by dentoalveolar and growth pattern compensation. These outcomes could be explained by changes in dental inclinations and by the increase of the posterior facial height, which minimized the effects of the longer anterior face height (Table 1).

\section{DISCUSSION}

The concern about facial vertical dimensions derives from the fact that they are more difficult to treat, and the results obtained are less stable ${ }^{15,20}$. An anterior open-bite 


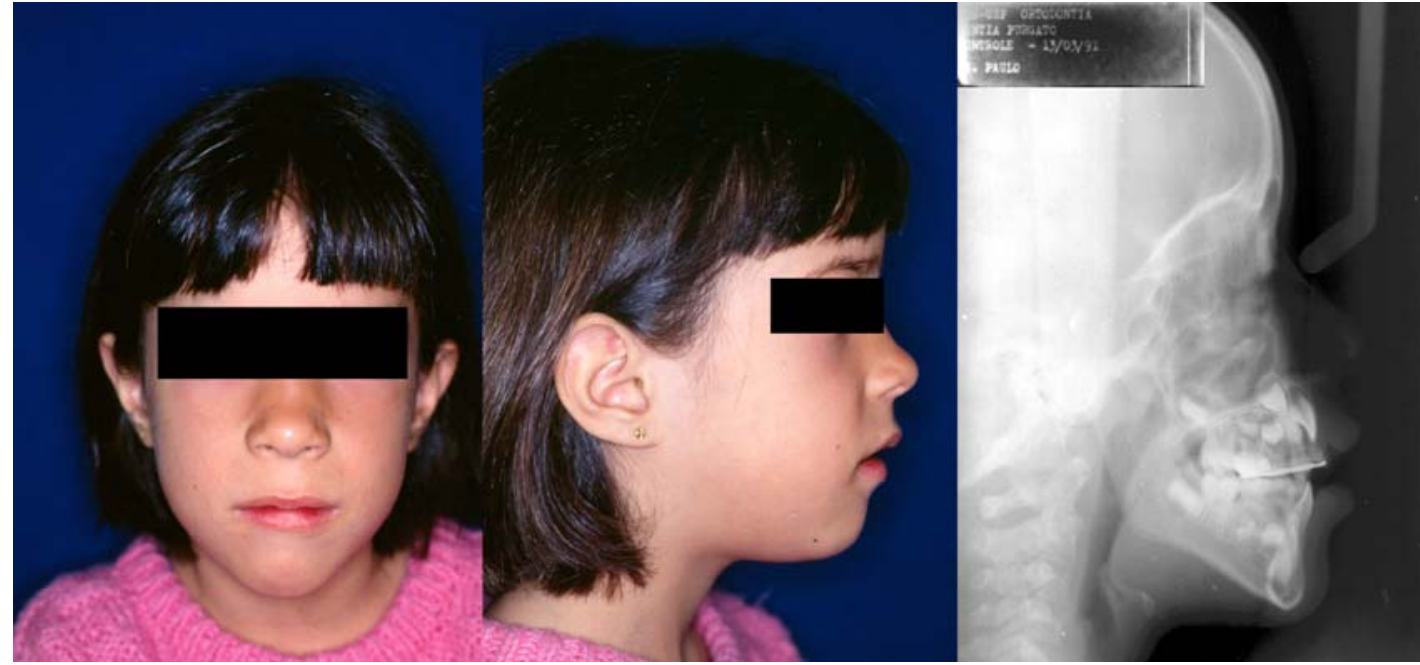

FIGURE 1- Frontal and lateral facial views and cephalometric lateral radiograph at the beginning of treatment ( 5 years and 2 months old)

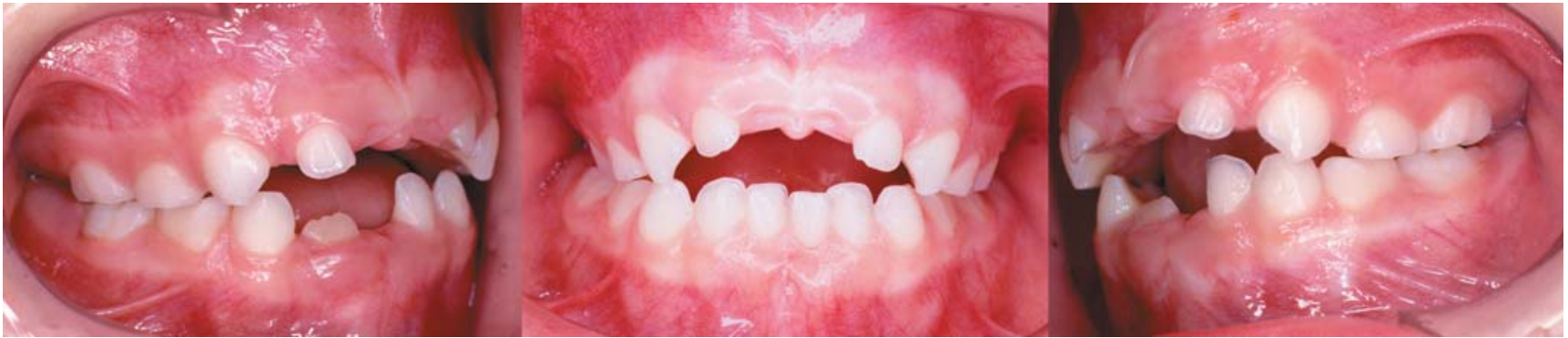

FIGURE 2- Lateral and frontal views at the beginning of treatment

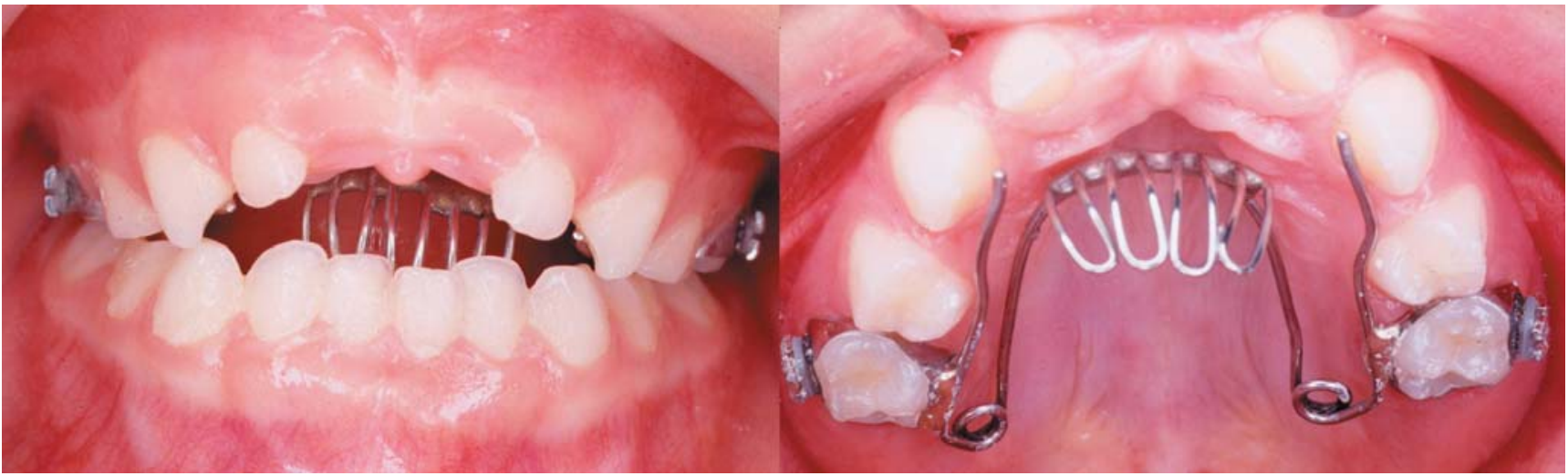

FIGURE 3- Frontal and occlusal views immediately after the placement of a fixed palatal crib soldered on the bi-helix

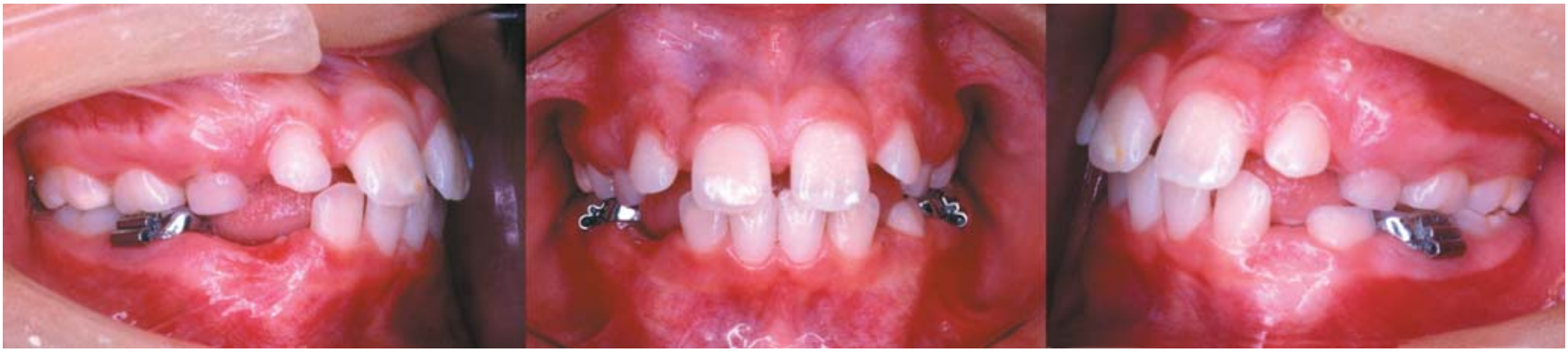

FIGURE 4- Frontal and lateral views after interceptive treatment (10 years old) 


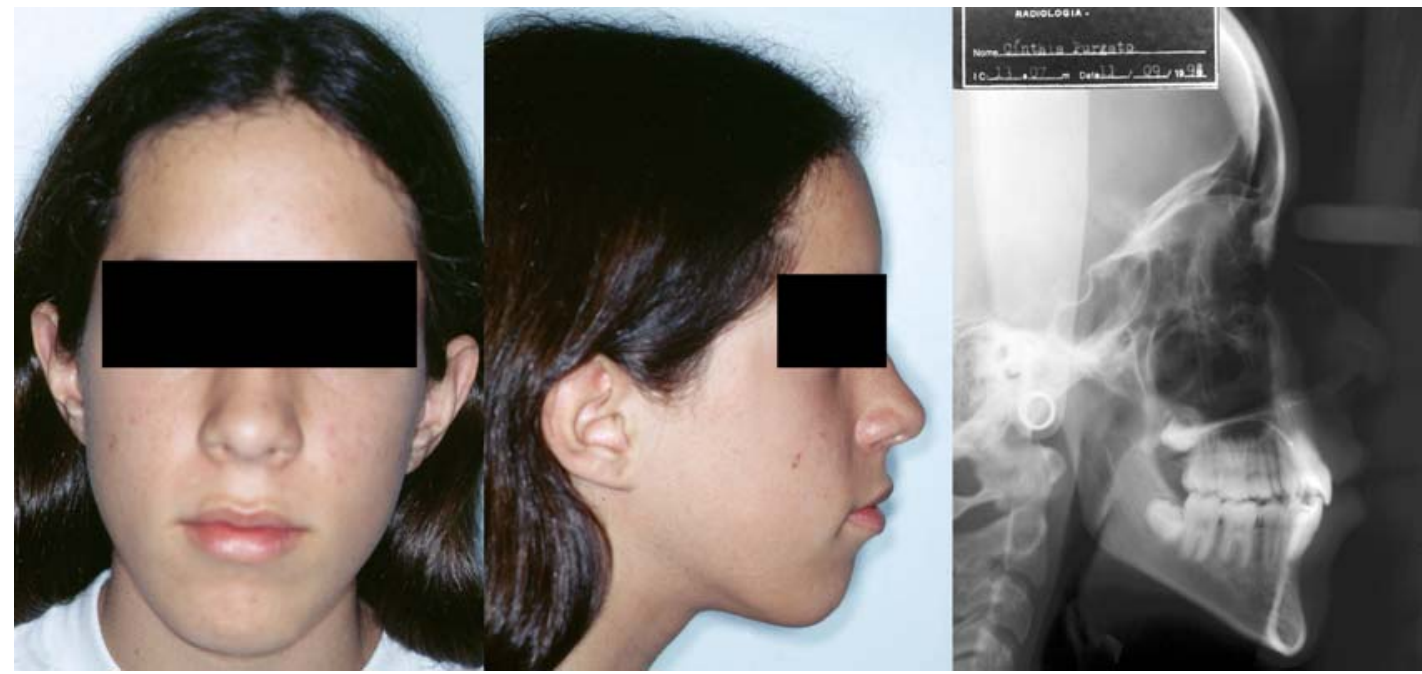

FIGURE 5- Frontal and lateral facial views and cephalometric lateral radiograph at the end of treatment (13 years and 7 months old)

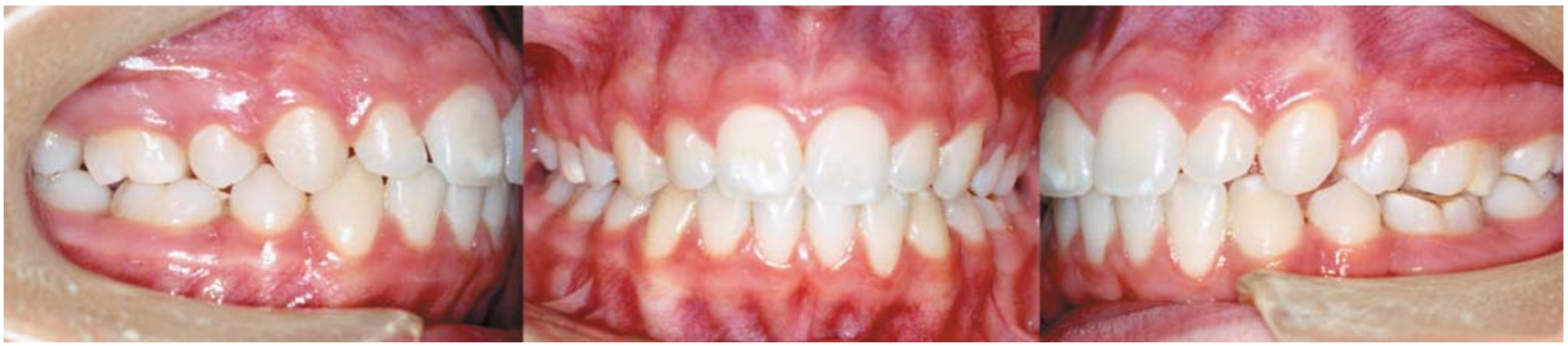

FIGURE 6- Frontal and lateral views at the end of treatment
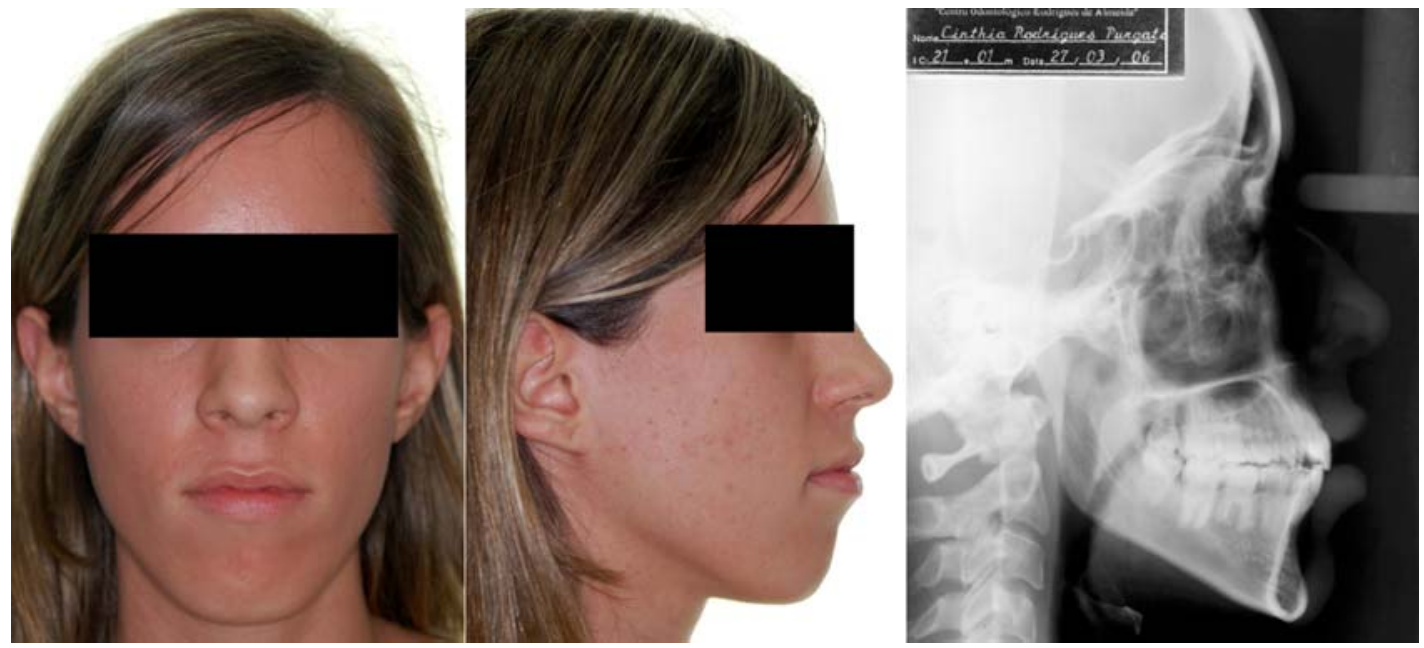

FIGURE 7- Frontal and lateral facial views and cephalometric lateral radiograph 8 years after treatment

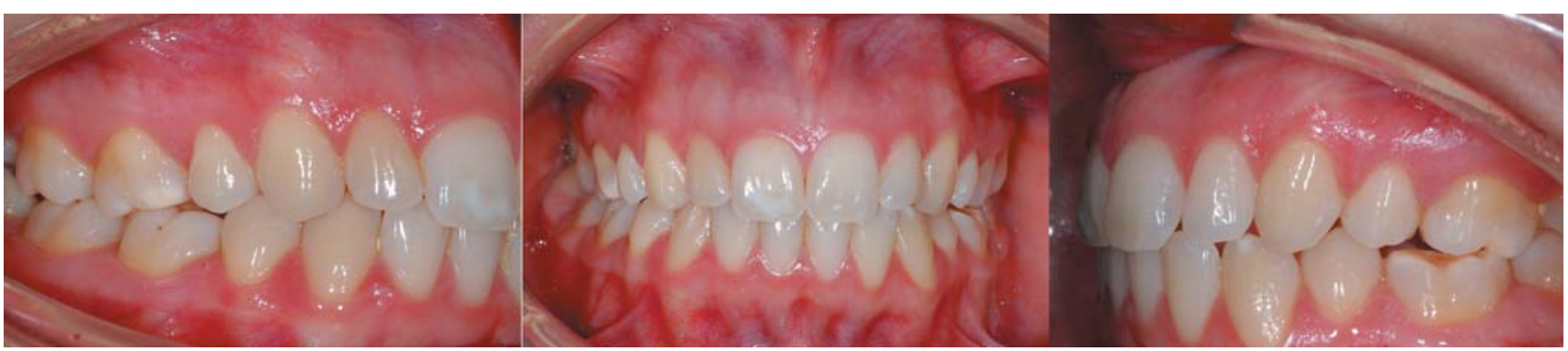

FIGURE 8- Frontal and lateral views 8 years after treatment 
may have a good or poor prognosis, depending on its etiology and severity. Relapse can reach $25 \%$. A prolonged habit, such as digital sucking, can lead to arrest of the vertical development of the alveolar process, lateral constriction of the maxilla due to increased activity of the perioral muscles, and a more inferior posturing of the tongue. This situation, in the majority of cases, causes posterior crossbite, high palate, extrusion of the posterior teeth and anterior displacement of the maxilla. If this condition remains for a lengthy period, the alterations may persist, even after the habit has been stopped ${ }^{9,21}$.

Therefore, during the mixed dentition, it is very important to treat patients adequately ${ }^{3,4}$, in order to avoid severe dental changes. These changes may become definitive, reducing the efficiency of the therapeutic methods, thus providing orthognathic surgery as the only option for treatment ${ }^{22}$.

The interruption of a habit can sometimes be traumatic to children, due to its importance in compensating psychological needs. Its sudden interruption can lead to a transfer to another habit, sometimes less socially accepted and more harmful to the child ${ }^{23}$. To a motivated patient, who sincerely wants to break a habit not psychologically significant, an appliance will work as a "reminder", and will help to break the habit. If the habit is compulsive, then psychological help is also required. Persistent thumbsucking may be a sign of a delay in development ${ }^{24}$.

Patients with open-bite often present incompetent upper lip and a compensatory hyperactive lower lip, orbicularis oris and tongue musculature. The anterior seal, necessary for swallowing, is obtained between the upper and lower incisors, contributing to maintenance of the negative overbite. Anterior open-bite can occur also as a consequence of abnormal skeletal growth. An individual with an excessive vertical growth has a good likelihood of developing an anterior open-bite, and the degree of its severity can be altered by unfavorable environmental factors, such as habits and mouth breathing ${ }^{7}$.

This case has been stable, and it is believed that it will remain so (Figures 7 and 8). This may be explained by the fact that treatments were conducted at the appropriate period of development, thus establishing perioral muscular equilibrium, matching the final period of facial growth. The combination of orthodontic and orthopedic treatments was necessary to achieve the best results, as previously suggested ${ }^{7}$. It must be pointed out that this patient, if not treated at the correct moment, could have required orthognathic surgery.

\section{REFERENCES}

1- Almeida RR, Almeida-Pedrin RR, Almeida MR, Ferreira FPC, Pinzan A, Insabralde CMB. Displasias Verticais: Mordida Aberta Anterior Tratamento e Estabilidade. Rev Dental Press. 2003;8(4):91-119.

2- Almeida RR, Ursi W. Anterior open-bite, etiology and treatment. Oral Health. 1990;80:27-31.

3- Pedrin F, Almeida MR, Almeida RR, Almeida-Pedrin RR, Torres F, A prospective study of the treatment effects of a removable appliance with palatal crib combined with high-pull chincup therapy in anterior open-bite patients. Am J Orthod Dentofacial Orthop. 2006;129(3):418-23.

4- Torres F, Almeida RR, Almeida MR, Almeida-Pedrin RR, Pedrin F, Henriques JFC. Anterior open-bite treated with a palatal crib and high-pull chin cup therapy. A prospective randomized study. Eur J Orthod. 2006;28(6):610-7.

5- Clemens C. Prevalência da mordida aberta anterior em escolares de Porto Alegre [Mestrado]. Porto Alegre: Universidade Federal do Rio Grande do Sul; 1977.

6- Worms FW, Meskin LH, Isaacson RJ. Open-bite. Am J Orthod Dentofac Orthop. 1971;59:589-95.

7- Graber TM, Rakosi T, Petrovic AG. Dentofacial orthopedics with functional appliances. Saint. Louis: Mosby; 1997.

TABLE 1- Cephalometric measures of the patient at the beginning, end of treatment and follow-up phase

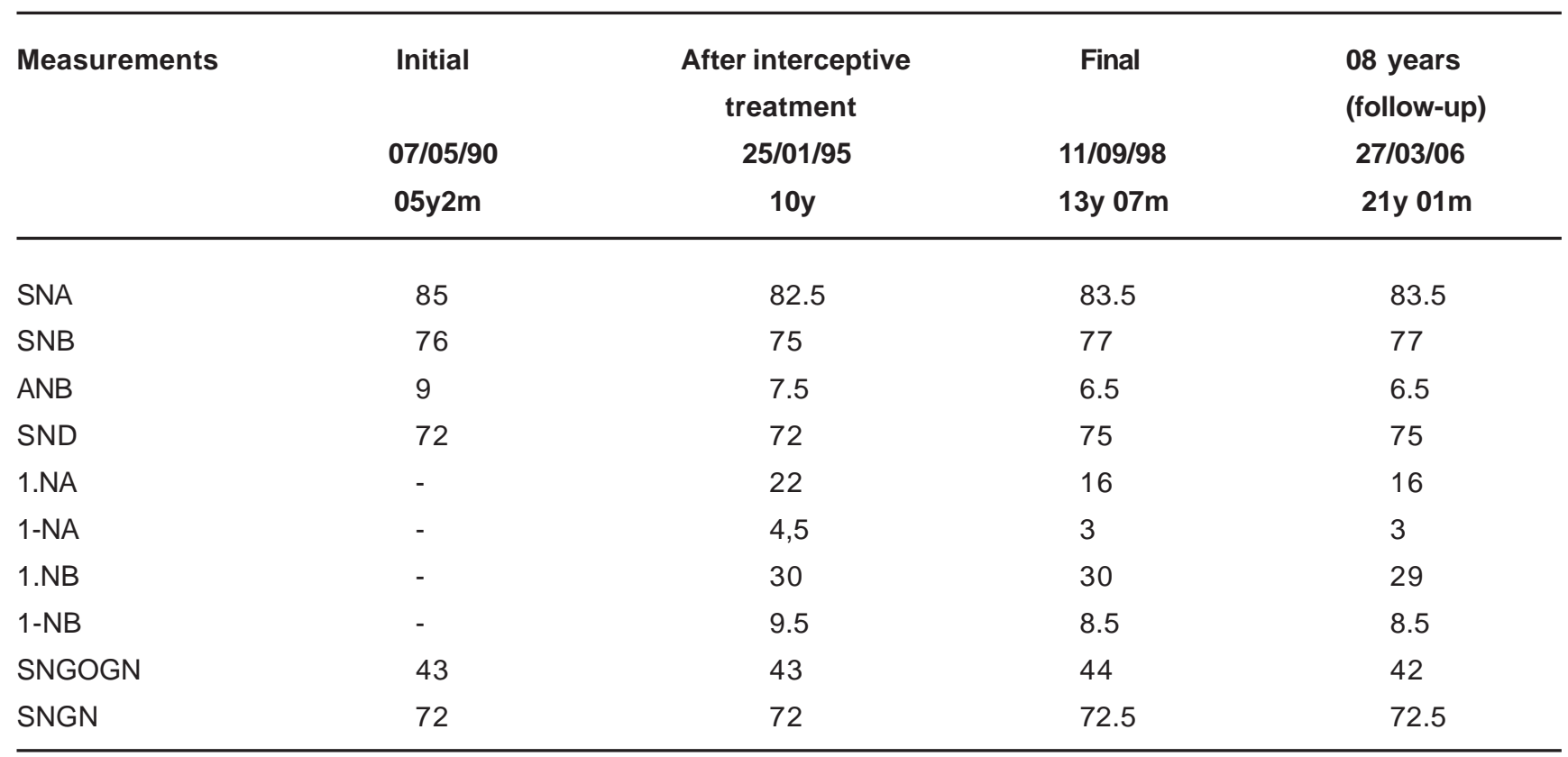


8- Hanson ML, Adrianopoulos MV. The tongue thrust and malocclusion. Int J Orthod. 1982;20:9-18.

9- Watson WG. Open-bite, a multifactorial event. Am J Orthod Dentofac Orthop. 1981;80:442-6.

10- Lopez-Gavito G, Wallen TR, Little RM, Joondeph R. Anterior open-bite malocclusion: a longitudinal 10 year post retention evaluation of orthodontically treated patients. Am J Orthod Dentofac Orthop. 1985;87:175-86.

11- Ngan P, Fields HW. Open-bite: a review of etiology and management. Pediatric Dent. 1997;19:91-8.

12- Speidel TM, Isaacson RJ, Worms FW. Tongue-thrust therapy and anterior dental open-bite. Am J Orthod Dentofac Orthop. 1972;32:287-95.

13- Proffit WR. Equilibrium theory revisited: Factors influencing position of the teeth. Angle Orthod 1978;48(3):175-86.

14- Fränkel R, Fränkel C. A functional approach to treatment of skeletal open-bite. Am J Orthod Dentofac Orthop. 1983;84:54-68.

15- Ellis E, McNamara Jr JA. Components of adult Class II open-bite malocclusion. J Oral Maxillofac Surg. 1985;42:92-105.

16- English JD. Early treatment of skeletal open-bite malocclusions. Am J Orthod Dentofac Orthop. 2002;121:563-5.

17- Pearson LE. Vertical control in treatment of patients having backward-rotational growth tendencies. Angle Orthod. 1978;48:13240 .

18- Janson G, Valarelli FP, Henriques JFC, Freitas MR, Cançado RH. Stability of anterior open-bite nonextraction treatment in the permanent dentition. Am J Orthod Dentofac Orthop. 2003;124:26576.

19- Richardson A. Skeletal factors in the anterior open-bite and deep bite. Am J Orthod Dentofac Orthop. 1969;56:115-27.

20- Nahoum HI. Vertical proportion and the palatal plane in anterior open-bite. Am J Orthod Dentofac Orthop. 1971;59:273-81.

21- Larsson E. Dummy and finger sucking habits with special attention to their significance for facial growth and occlusion. Swed Dent 1978;2:23-33.

22- Silva Filho OG, Gonçalves RMG, Maia FA. Sucking habits: clinical managements in dentistry. J Clin Ped Dent. 1991;15:137-56.

23- Justus R, 1976. Tratamiento de la mordida abierta anterior: um estdio cefalometrico y clinico. Rev Ass Dent Mex. 1976;6:17-40.

24- Graber TM. Thumb and finger sucking. Am J Orthod Dentofac Orthop. 1959;45:258-64. 